\title{
VALIDATING A DEFENSE-SPECIFIC CLUSTER CONCEPTUAL MODEL USING STATISTICAL INSTRUMENTS
}

\author{
Gabriel MĂNESCU \\ "Nicolae Bălcescu" Land Forces Academy, Sibiu, Romania \\ manescug@yahoo.com
}

\begin{abstract}
The paper shows how statistical tools can be used for modeling testing and validating. In this sense, the paper presents an example of how to use SPSS for validating a cluster conceptual model for scientific research in the field of defense. The steps taken and the results obtained are presented in detail by correlating the most important characteristics of foreign and domestic clusters in the field of defense and in related domains, with a high potential of applicability in this area. The illustrated correlations fully support the lessons learned from the application of this method.
\end{abstract}

\section{Keywords: Cluster, conceptual model, SPSS, validation.}

\section{Introduction}

The simplest description of clusters is based on the description of the relationships established between the supplier and the customer and the value chain created by them.

The functioning of companies in the framework of such entities leads them to obtain a competitive advantage, as they have a dense network of suppliers and customers nearby.

With regard to the term "value chain", it derives from Alfred Marshall's concept (1842-1924) who noted that "the geographical concentration of a particular sector determines the specialization of the suppliers" [1].

Currently, the most widely used definition of the term cluster is given by the person who is responsible for popularizing this concept, Professor Michael Porter (1998): "Clusters are geographic concentrations of interconnected companies and institutions, which are manifested in a particular field" [2].

At the level of our country, designing a defense cluster could contribute to the economic recovery of the defense industry, to building up cooperation between higher military / civilian education institutions and local authorities and not least, would have a significant impact on the local / regional economic environment [3].

\section{The object of the study}

The initiative to form a cluster may be defined as an organized effort towards increasing the growth and competitiveness of a particular clusters in a region, an action involving a group of companies, central / local authorities and the academic / research environment [4].

A larger study conducted between 20132015 identified the main characteristics of a defense cluster conceptual model. This model has also been tested as part of the study [5].

\section{Validating the collaborative model}

In order to validate the model, we will further show the manner of correlating the most important features (available data) of three identified clusters (EDEN France Cluj IT Romania, PRELMET Transylvania) with 
the collaborative cluster model Romanian Defense Cluster (RDC).

EDEN "is a French cluster that brings together the most important French defense companies and not only. The particularity of this cluster consists of its inter-regional dimension, and each region is represented by entities of the same type" [6].

Cluj IT cluster "is perhaps the most famous cluster in our country and probably the most active one. It is a regional cluster

composed of active organizations in the field of information technology" [7].

PrelMET Transilvania cluster "is an emerging cluster built in an area with strong traditions in metalworking. We chose this cluster due to the fact that some of the entities composing it belong to several companies in the defense sector" [8].

The main features taken into account are shown in the following table:

Table 1. Main charactieristics of the clusters

\begin{tabular}{|l|c|c|c|c|}
\hline & $\begin{array}{c}\text { EDEN } \\
\text { France }\end{array}$ & $\begin{array}{c}\text { Cluj IT } \\
\text { Romania }\end{array}$ & $\begin{array}{c}\text { PrelMET } \\
\text { Transilvania }\end{array}$ & RDC \\
\hline Size & 81 & 41 & 27 & 12 \\
\hline Civilian companies & 62 & 29 & 15 & 3 \\
\hline $\begin{array}{l}\text { Authorities/Management } \\
\text { agencies }\end{array}$ & 8 & 8 & 8 & 2 \\
\hline Employees & 6500 & 3629 & 481 & 6450 \\
\hline 2013 turnover & $650.000 .000 €$ & $175.092 .740 €$ & $102.253 €$ & $7.000 .000 €$ \\
\hline $\begin{array}{l}\text { Overall indicator of the } \\
\text { cluster }\end{array}$ & 122 & 62 & 41 & 18 \\
\hline
\end{tabular}

(source: own interpretation)

Thus, the collaborative model of scientific research in institutions in the field of defense (RDC) is validated by analyzing and interpreting the statistical correlation, respectively by "linking" it to real "tangible" elements, measurable by recognized, verifiable methods.
The data collected through bibliographic research was typed in a file automatically receiving the SPSS .sav. The program processed the variables and the values assigned to them in the Data Editor window. This includes the secondary windows: Variable View and Data View.

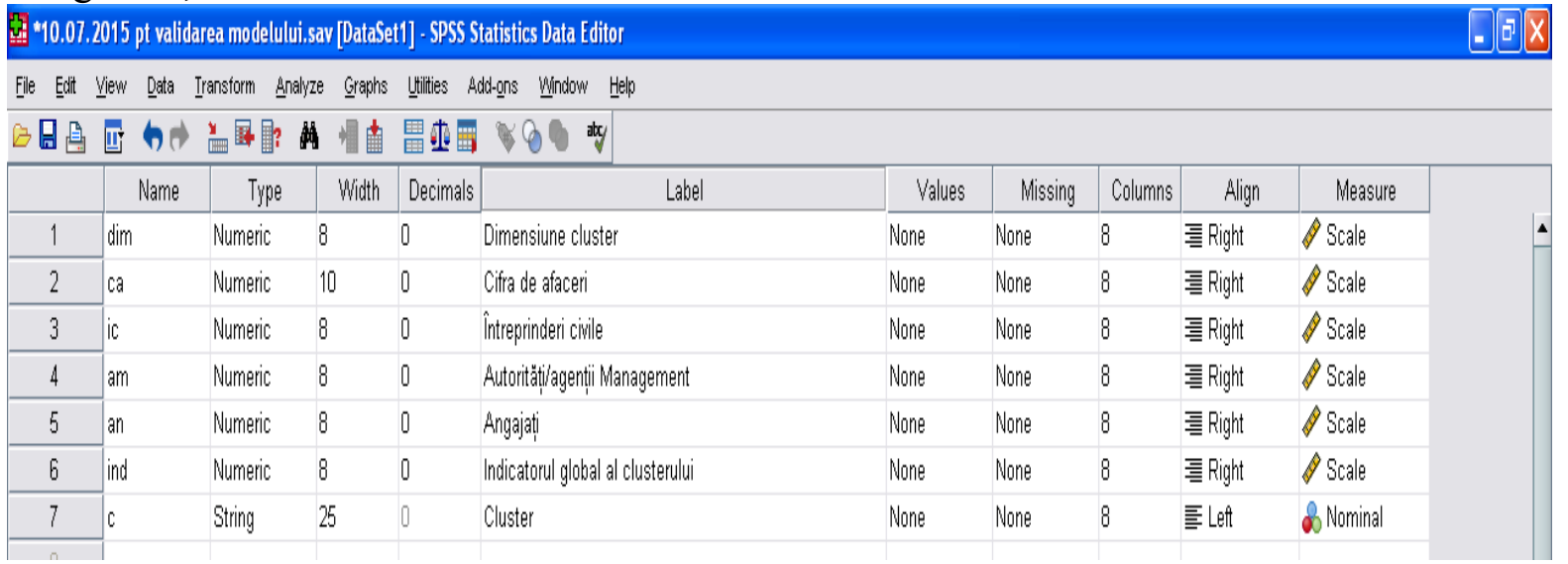

Figure 1. Variable View secondary window 


\begin{tabular}{|c|c|c|c|c|c|c|c|c|c|c|c|c|c|c|}
\hline \multicolumn{13}{|l|}{ 15: } & \multicolumn{2}{|c|}{ Visible: 7 of 7 Variables } \\
\hline & dim & $C A$ & ic & am & an & ind & $c$ & var & var & var & var & var & var & var \\
\hline 1 & & 6500000000 & 6 & & 6500 & & Franta & & & & & & & $\Delta$ \\
\hline 2 & & 175992740 & 2 & & 3629 & & Românalia & & & & & & & \\
\hline 3 & & 102253 & 1 & & 481 & & TT Transilvarila & & & & & & & \\
\hline 4 & & 7000000 & & & 6450 & & & & & & & & & \\
\hline
\end{tabular}

Figure 2. Data View secondary window

"The correlation is a statistical method used to determine the relationship between two or more variables, while the correlation coefficient is a quantitative value that describes the relationship between two or more variables. It varies between -1 and +1 , where extreme values describe a perfect relationship between variables, and 0 means a complete lack of linear relationship. The most widely used is the Pearson correlation coefficient (r) for normal (uniformly) distributed values and the Spearman correlation coefficient (rs) for nonuniformly distributed values"[9].

The Pearson correlation coefficient (r) is independent of the measurement unit. It measures the association between two variables. This refers to the intensity and direction of paralel variation of the values

of a variables in co-relation another, according to a linear model. If the values of a variable are in direct, upward direction, or vice versa, are decreasing, as compared to the values of the other variable, then the two variables correlate with each other. The range of the Pearson correlation coefficient ( $\mathrm{r}$ ) is between $\mathrm{r}=-1$ (perfect negative correlation: which means that, while the scores of a variable increase, the scores the other variables decrease) and $r=+1$ (perfect positive correlation: which means that the scores of a variable increases at the same time as the scores of the other variable). The absence of any relationship (correlation) between the variables translates as $r=0$ [10].

In the following table we present how can be used the Pearson correlation coefficient:

Table 2. Interpretation of Pearson coefficient

\begin{tabular}{ll}
$\begin{array}{l}\text { Interval of the Pearson correlation } \\
\text { coefficient }(r)\end{array}$ & \multicolumn{1}{c}{ Interpretation of Pearson coefficient } \\
\hline$[0 ; 0.2]$ & very low intensity correlation \\
{$[0.2 ; 0.4]$} & low intensity correlation \\
{$[0.4 ; 0.6]$} & reasonable correlation, of average/moderate intensity \\
{$[0.6 ; 0.8]$} & high intensity correlation \\
{$[0.8 ; 1]$} & very high intensity correlation \\
\end{tabular}

For the analysis of the bivariate correlation we performed the following sequence of commands: Analyze $\rightarrow$ Correlate $\rightarrow$ Bivariate $\rightarrow$ Bivariate Correlations window, from which we obtained the
Pearson coefficient information shown in Table 3, for the variables "Cluster size" and "Turnover" and Table 4 respectively, for the variables"Civilian companies" and "Turnover": 
Table 3. Pearson correlation coefficient for"Cluster size" and "Turnover"variables

\begin{tabular}{|c|c|c|c|}
\hline & & Cluster size & Turnover \\
\hline Cluster size & $\begin{array}{l}\text { Pearson Correlation } \\
\text { Sig. (2-tailed) } \\
\mathrm{N}\end{array}$ & 4 & $\begin{array}{l}, 973^{*} \\
027 \\
4\end{array}$ \\
\hline Turnover & $\begin{array}{l}\text { Pearson Correlation } \\
\text { Sig. (2-tailed) } \\
\mathrm{N}\end{array}$ & $\begin{array}{l}973^{*} \\
027 \\
4\end{array}$ & $\begin{array}{l}1 \\
4\end{array}$ \\
\hline
\end{tabular}

Table 4. Pearson correlation coefficient for" Civilian companies" and "Turnover"variables

\begin{tabular}{|l|l|l|l|}
\hline \multicolumn{2}{|l|}{} & $\begin{array}{l}\text { Civilian } \\
\text { companies }\end{array}$ & Turnover \\
\hline \multirow{4}{*}{ Civilian companies } & Pearson Correlation & 1 & $1,000^{*}$ \\
& Sig. (2-tailed) & &, 019 \\
& $\mathrm{~N}$ & 4 & 4 \\
\hline \multirow{3}{*}{ Turnover } & Pearson Correlation & $1,000^{*}$ & 1 \\
& Sig. (2-tailed) &, 019 & 4 \\
\hline
\end{tabular}

In Tables 3 and 4 "we obtained the matrix of the correlation coefficients. The values are distributed on both sides of the diagonals of the table. The correlation coefficients equal to 1 represent the correlation of each variable with itself, while the other diagonal of the tables shows the values of the correlation coefficient between the variables" [11].

Figure 3 highlights the analyzed clusters and their overall indicator.

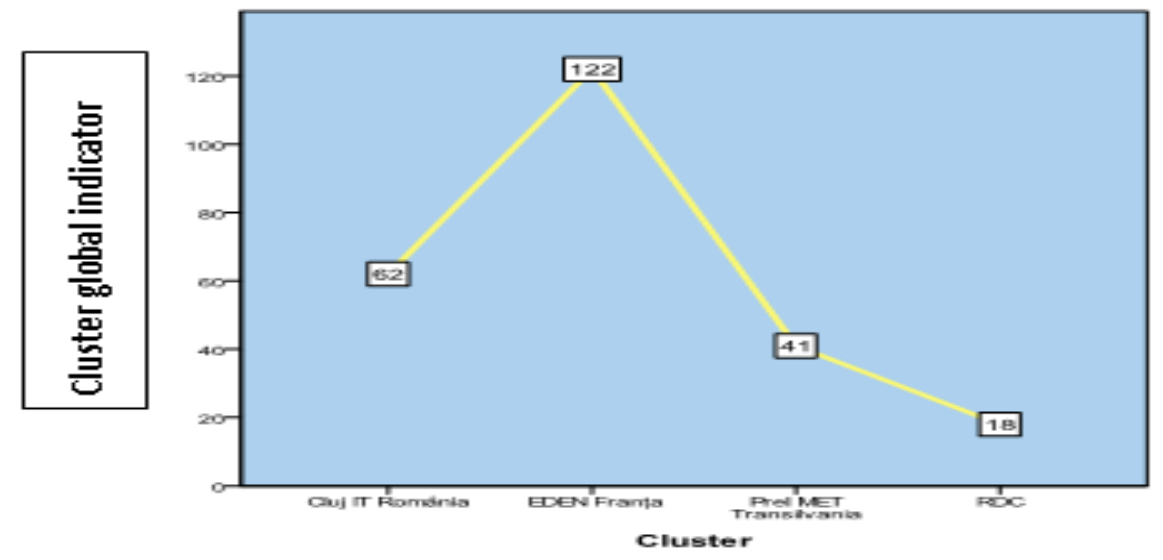

Figure 3. Clusters and global indicators

Furthermore, by performing the sequence of commands: Analyze $\rightarrow$ Correlate $\rightarrow$ Bivariate $\rightarrow$ Bivariate Correlations window, we obtained information about the
Pearson coefficient shown in Tables 9.8.9.12., for the variable "Cluster global indicator" and the other variables: 
Table 5. Pearson correlation coefficient for "Cluster global indicator" and

\begin{tabular}{|c|c|c|c|}
\hline & & Cluster global indicator & Cluster size \\
\hline $\begin{array}{l}\text { Cluster global } \\
\text { indicator }\end{array}$ & $\begin{array}{l}\text { Pearson Correlation } \\
\text { Sig. (2-tailed) } \\
\mathrm{N}\end{array}$ & $\begin{array}{l}1 \\
4\end{array}$ & $\begin{array}{l}1,000^{* *} \\
, 000 \\
4\end{array}$ \\
\hline Cluster size & $\begin{array}{l}\text { Pearson Correlation } \\
\text { Sig. (2-tailed) } \\
\mathrm{N}\end{array}$ & $\begin{array}{l}1,000^{* *} \\
000 \\
4\end{array}$ & $\begin{array}{l}1 \\
4\end{array}$ \\
\hline
\end{tabular}

Table 6. Pearson correlation coefficient for "Cluster global indicator" and

\begin{tabular}{|l|l|l|l|}
\hline \multicolumn{2}{|c|}{} & Cluster global indicator & Turnover \\
\hline \multirow{2}{*}{$\begin{array}{l}\text { Cluster global } \\
\text { indicator }\end{array}$} & Pearson Correlation & 1 &, $972^{*}$ \\
& Sig. (2-tailed) & &, 028 \\
& N & 4 & 4 \\
\hline \multirow{3}{*}{ Turnover } & Pearson Correlation &, $972^{*}$ & 1 \\
& Sig. (2-tailed) &, 028 & \\
& N & 4 & 4 \\
\hline
\end{tabular}

Table 7. Pearson correlation coefficient for "Cluster global indicator" and "Civilian companies" variables

\begin{tabular}{|l|l|l|l|}
\hline \multicolumn{2}{|c|}{} & Cluster global indicator & Civilian companies \\
\hline $\begin{array}{l}\text { Cluster global } \\
\text { indicator }\end{array}$ & Pearson Correlation & 1 &, $999^{* *}$ \\
& Sig. (2-tailed) & &, 001 \\
& N & 4 & 4 \\
\hline Civilian & Pearson Correlation &, $999^{* *}$ & 1 \\
companies & Sig. (2-tailed) &, 001 & 4 \\
\hline
\end{tabular}

Table 8. Pearson correlation coefficient for" Cluster global indicator" and "Authorities/Management Agencies" variables

\begin{tabular}{|l|l|l|l|}
\hline \multicolumn{2}{|l|}{} & $\begin{array}{l}\text { Cluster global } \\
\text { indicator }\end{array}$ & $\begin{array}{l}\text { Authorities/ } \\
\text { Management Agencies }\end{array}$ \\
\hline $\begin{array}{l}\text { Cluster global } \\
\text { indicator }\end{array}$ & Pearson Correlation & 1 &, 639 \\
& Sig. (2-tailed) & &, 361 \\
& N & 4 & 4 \\
\hline Authorities/ & Pearson Correlation &, 639 & 1 \\
Management & Sig. (2-tailed) &, 361 & \\
Agencies & N & 4 & 4 \\
\hline
\end{tabular}

Table 9. Pearson correlation coefficient for" Cluster global indicator" and "Employees" variables

\begin{tabular}{|l|l|l|l|}
\hline \multicolumn{2}{|l|}{} & $\begin{array}{l}\text { Cluster global } \\
\text { indicator }\end{array}$ & Employees \\
\hline $\begin{array}{l}\text { Cluster global } \\
\text { indicator }\end{array}$ & Pearson Correlation & 1 &, 307 \\
& Sig. (2-tailed) & &, 693 \\
& N & 4 & 4 \\
\hline \multirow{3}{*}{ Employees } & Pearson Correlation &, 307 & 1 \\
& Sig. (2-tailed) &, 693 & 4 \\
\hline
\end{tabular}




\section{Conclusions}

1. The correlation shown in Tables 3 and 4 is bivariate, one of the variables is dependent and the other one independent (factorial). The Pearson correlation coefficient is equal to 0.973 and 1.000 respectively, which means that there is a linear, positive (direct), very high intensity correlation between the analyzed variables. The development of the clusters during their life cycle is very strongly linked to the development of their turnover and collaboration with civilian companies.

2. The Pearson correlation coefficients displayed by the SPSS in Tables 5., 6. and 7. (1;0.972; $0.999 ;)$, show a very strong very high intensity correlation between "Cluster global indicator" and "Cluster size", "Civilian companies" and "Turnover".

3. The Pearson correlation coefficient displayed by the SPSS software in Table 8 . (0.639), indicates a strong link, a high intensity correlation between "Cluster global indicator"and Authorities/ Management Agencies".

4. The Pearson correlation coefficient displayed by SPSS in Table 9. (0.307) shows a low intensity correlation between "Cluster global indicator" and the volume of thevariable "Employees".

5. The model called "Cluster global indicator" is validated by the fact that it has been built to correlate with real, verifiable elements, measurable by established methods.

[1] Marshall, A., Principles of Economics, 1890, available at: http://www.econlib.org/library/Marshall/marP.html

[2] Porter, M. „Clusters and the new economics of competition”. Boston, Harvard Business Review, 1998.

[3] Mănescu, G., \& Kifor, C „The Clusters - Collaborative Model of Sustainable Regional Development". ACTA Universitatis Cibiniensis, Technical Series, Vol. LXV/2014, ISSN (Online) 1583-7149, DOI: https://doi.org/10.1515/aucts-2015-0010.

[4] Mănescu, G., Cercetări privind realizarea unui model colaborativ al cercetării ştiințifice in institutiile din domeniul apărării, Teză de doctorat, Universitatea "Lucian Blaga" din Sibiu, 2015a.

[5] Ibidem;

[6] Mănescu G., PhD Thesis Abstract, 2015, Research on Achieving a Collaborative Model of Scientific Research in Defense Institutions, available at: http://doctorate.ulbsibiu.ro/obj/documents/REZUMATTEZA_MANESCU_ENG.pdf

[7] Ibidem;

[8] Ibidem;

[9] Ibidem;

[10] Jaba, E., \& Grama, A. Analiza statistică cu SPSS sub Windows. Iași. Editura Polirom, 2005.

[11] Mănescu G., PhD Thesis Abstract, 2015, Research on Achieving a Collaborative Model of Scientific Research in Defense Institutions, available at: http://doctorate.ulbsibiu.ro/obj/documents/REZUMATTEZA_MANESCU_ENG.pdf 